\title{
Seismic Response of LNG Storage Tanks under Earthquake Excitations
}

\author{
Iraj H.P. Mamaghani' ${ }^{1}$, Wiryachai RoopKumdee ${ }^{2}$ \\ ${ }^{1}$ Associate Professor, Department of Civil Engineering, University of North Dakota \\ Grand Forks, ND 58201, USA \\ Iraj.mamaghani@und.edu \\ ${ }^{2}$ Graduate Student, Department of Civil Engineering, University of North Dakota \\ Grand Forks, ND 58201, USA \\ wiriyachai.roopkumde@und.edu
}

\section{Extended Abstract}

This paper deals with seismic response of liquefied natural gas (LNG) storage tanks under earthquake Excitations. LNG storage tanks represent strategic infrastructure for energy supplies all over the world. LNG is natural gas that has been cooled to a temperature around $-162^{\circ} \mathrm{C}$, whereby it condenses into a liquid form. The main benefit of the cooling is that the LNG is reduced to around 0.17 percent of its volume as a gas form. It also weighs only about 45 percent of an equivalent amount of water [1,2]. LNG storage tanks are classified in three different types. Single containment tank is either a single tank or a tank comprising an inner tank and outer container designed and constructed so that only the inner tank is required to meet the low temperature ductility requirements for storage of the product. A double containment tank is a tank designed and constructed so that the inner tank is capable of liquid and vapor tight containing, and the outer tank is capable of liquid tight containing. Full containment tank is described as a double tank designed and constructed so that both the inner and outer tank are capable of liquid and vapor tight containing. The inner tank is manufactured with $9 \%$ nickel steel. The $9 \%$ nickel steel is widely used as a material for the inner tank since it has strength and toughness enough for the cryogenic uses [1,2].

LNG storage tanks carry a significant risk related to possible consequences of incidents caused by natural events such as earthquake excitations. Nevertheless, the knowledge is limited to the seismic behaviour of the LNG storage tanks when they are subjected to strong earthquake excitations. In this study, the seismic capability of LNG storage tank is evaluated for severe earthquake excitations. The effects of an intensive parameters on seismic response have been evaluated. An intensive parametric study is conducted to investigate the effect of main design parameters of circular thin-walled steel LNG storage tanks including: radius-to-thickness ratio parameter $\left(R_{t}\right)$, slenderness ratio parameter $(\lambda)$, liquid-filled ratio $\left(h_{l} / h\right)$ in which $h_{l}=$ height of filled liquid and $h=$ height of tank, modified effective length $\left(L_{c}\right)$, and effective plate width for stiffener $\left(b_{e}\right)$. In additional, the effect of the longitudinal, ring, and two-way stiffeners on static and seismic resistance is investigated. It is found that the strength and ductility of circular thin-walled steel LNG storage tanks depend on $R_{t}$ and $\lambda$. Moreover, decreasing $R_{t}$ and $\lambda$ improve the strength and ductility of these LNG storage tanks. Design specifications for $L_{c}$ and $b_{e}$ are evaluated as the important parameters for the LNG storage tanks.

\section{References}

[1] American Petroleum Institute (API) 620: Recommended Rules for Design and Construction of Large, Welded Low Pressure Storage Tanks.

[2] British Standard (BS) 7777: Flat-Bottomed Vertical, Cylindrical Storage Tanks for Low Temperature Service. 